\title{
Risk of Prostate Cancer and Cyclin D1 A870G polymorphism; a Study of Correlation
}

Firdous Hussain $^{1}$, Arif Hamid ${ }^{2}$, and Rita Singh Majumdhar ${ }^{1^{*}}$

${ }^{1}$ Department of Biotechnology, Sharda University, Greater Noida, India

${ }^{2}$ Department of Urology, S.k Institute of Medical Sciences, Srinagar, India

*Corresponding author: Rita Singh Majumdhar, Department of Biotechnology, Sharda University, Greater Noida, India, Tel: +917889454342; E-mail: firdousbeigh@gmail.com

Received date: April 19, 2017; Accepted date: May 14, 2017; Published date: May 19, 2017

Copyright: (C) 2017 Hussain F, et al. This is an open-access article distributed under the terms of the Creative Commons Attribution License, which permits unrestricted use, distribution, and reproduction in any medium, provided the original author and source are credited.

\begin{abstract}
Cyclin D1 (CCND1) is a critical gene in regulating the progression of cell cycle from G1 to S phases. Like other cyclins, cyclin D1 is frequently dysregulated in multiple cancers. Various clinical and epidemiological studies have suggested the possible association of cyclin D1 A870G polymorphism with the development of various cancers. Hence, we investigated the role of cyclin D1 A870G polymorphism in modulating the risk of prostate cancer (CaP) in a Kashmiri population. We examined a case-control study in which $129 \mathrm{CaP}$ cases were studied for cyclin D1 A870G polymorphism against 221 controls taken from the general population by employing the polymerase chain reaction-restriction length fragment polymorphism technique. We observed the cyclin D1 $A$ allele was more frequently present in the $\mathrm{CaP}$ group than the control group. Furthermore, men with AA genotype have an increased risk for developing $\mathrm{CaP}$ as compared to the control groups. We found AA genotype statistically significantly associated with dwelling, lymph node metastases, histopathological grade, and PSA levels. Therefore, our findings suggest that $A 870 G$ polymorphism is a risk factor for CaP development. Furthermore, men with AA genotype have an increased risk of developing $\mathrm{CaP}$.
\end{abstract}

Keywords: CaP; Cyclin D1; Genetic polymorphism

\section{Introduction}

Prostate cancer $(\mathrm{CaP})$ is a complex disease caused by multiple factors, and is one of the most frequent malignant diseases among men [1]. Accumulating studies have revealed the association of various genetic elements in the development of sporadic $\mathrm{CaP}[2,3]$, which might be used as potential therapeutic targets for $\mathrm{CaP}$ therapy. Hence, studying the role of genetic variants including single nucleotide polymorphic is of great significance in understanding the susceptibility $\mathrm{CaP}$.

An unbalance in the cell cycle regulation has been found to play a key role in a various type of cancers, and is often associated with the onset of metastasis, in part, by negatively modulating the cell's ability to respond appropriately to DNA damage [4,5]. Reports have suggested that a strong relation between the alleles of these genes and $\mathrm{CaP}$ susceptibility [6-10]. Cyclin $D 1$, also known as CCND1, is confined to the nucleus during G1 phase, and plays a pivotal role in the progression from the G1 to S phase of cell cycle [11]. During the CaP development, the expression of cyclin D1 gene has often been seen overexpressed and is associated to poor prognosis of $\mathrm{CaP}$ [12-14]. These findings indicate the importance of cyclin D1 (as a cell-cycle regulator) in carcinogenesis and progression of $\mathrm{CaP}$ [15].

Cyclin D1 mRNA is alternatively spliced into two different transcripts, which get translated into two different proteins $[16,17]$. The $A 870 G$ polymorphism appears to modulate the splicing at codon 242 within conserved donor site of exon 4 of the gene [16-18]. Recent studies have suggested that the variant allele encoding $\mathrm{A}$ is a major source of variant transcript $b$ in several kinds of cancer cells [16-18].
Moreover, cyclin D1 genotypes have been frequently found associated to variety of cancers $[16,18,19-21]$.

Therefore, considering the importance of cyclin D1 in the development of $\mathrm{CaP}$, the present study was conducted to investigate the association between the Cyclin D1 A870G polymorphism and the susceptibility to $\mathrm{CaP}$ or its disease status.

\section{Materials and Methods}

\section{Prostate cancer patients}

A cohort of $129 \mathrm{CaP}$ tissue samples were collected, with the histopathological diagnosis of the CaP. All the samples included in this study consisted of tumor and adjacent normal tissues. Only the tissue samples confirmed by histopathological studies to be cancerous were included in the study. The patient participation was obtained through informed consent and after approval from the Ethics Committee of Sher-I-Kashmir Institute of Medical Sciences.

The patients underwent histopathological diagnosis in the Department of Histopathology of our institution. Fifty prostate tumor samples and 45 benign hyperplasia (BHP) samples were collected. Samples from 80 healthy males over 50 years of age served as the controls. We also obtained prostate sextant biopsy specimens from 10 patients with elevated levels of serum PSA. Prostate cancer tissue samples consisting of tumor tissues and adjacent normal tissue were collected. Only histo-pathologically confirmed tumors were included in the study. The study was approved by the Ethical Committee of the Sher-i-Kashmir Institute of Medical Sciences. 
Page 2 of 4

\section{Controls}

Patients attending the Department of general medicine at Sher-IKashmir Institute of Medical Sciences (SKIMS) for general checkup were screened. A total of 260 patients visited the SKIMS, out of 260 patients only 221 agreed to take part in the present study, henceforth written informed consent was obtained from all patients for their participation.

\section{A870G gene polymorphism}

The $A 870 G$ polymorphism lies within the conserved splice donor site of exon 4 of cyclin D1 gene. This SNP was detected by restriction fragment length polymorphism of PCR-amplified fragments. PCR reactions were carried out in a final volume of $25 \mu \mathrm{L}$ containing $50 \mathrm{ng}$ genomic DNA template, 1X PCR buffer (Biotools) with $2 \mathrm{mM} \mathrm{MgCl}_{2}$, $0.4 \mu \mathrm{M}$ of each primer (Genescript), $50 \mu \mathrm{M}$ dNTPs (Biotools), and 0.5 U DNA polymerase (Biotools). For PCR amplification, the standard program was used as follows: After an initial denaturation step at $94^{\circ} \mathrm{C}$ for $7 \mathrm{~min}$, followed by 35 denaturation cycles of $30 \mathrm{~s}$ at $94^{\circ} \mathrm{C}, 30 \mathrm{~s}$ of annealing at $54^{\circ} \mathrm{C}$, and 30 s of exten $\neg$ sion at $72^{\circ} \mathrm{C}$, followed by a final elongation cycle at $72^{\circ} \mathrm{C}$ for $5 \mathrm{~min}$. The amplified product was digested overnight with the ScrFI enzyme at $37^{\circ} \mathrm{C}$ and electrophoresed on a $3.0 \%$ agarose gel. Restriction fragments obtained were 146 and $22 \mathrm{bp}$ for the $\mathrm{G}$ homozygote, and the unrestricted fragment was $167 \mathrm{bp}$ for the A homozygote, while as the heterozygote displayed both the two bands.

\section{Statistical analysis}

Observed frequencies of genotypes in $\mathrm{CaP}$ patients were compared to controls using chi-square or Fisher exact tests when expected frequencies were small. The chi-square test was used to verify whether genotype distributions were in Hardy-Weinberg equilibrium. Statistical significance was set at $\mathrm{P}<0.05$. Statistical analyses were performed with PASW version 18 Software.

\section{Results}

We determined the $A 870 G$ polymorphism in $129 \mathrm{CaP}$ patients; $22.4 \%$ (29 of 129) of the patients were homozygous for G/G variant, $27.9 \%$ (36 of 129) were heterozygous for $\mathrm{A} / \mathrm{G}$ and $49.61 \%$ (64 of 129) were homozygous for A/A variant. Whereas the pattern of A870G polymorphism in 221 healthy controls is $11.31 \%$ ( 25 of 221 ) of the patients were homozygous for A/A variant, $48.86 \%$ (108 of 221) were heterozygous for $\mathrm{A} / \mathrm{G}$ and $20.81 \%$ (46 of 221 ) were homozygous for $\mathrm{G} / \mathrm{G}$ variant.

The present study consisted of $129 \mathrm{CaP}$ patients, out of which 116 patients were above or equal to 65 years of age and 13 were of 50 years of age. Most of our patients (72) had grade I \& II tumor, and 57 had grade III \& IV tumor status. $104 \mathrm{CaP}$ patients had widely or moderately differentiated histo-pathological grade and 25 had poorly differentiated histo-pathological grade. Men aged 65 years or over formed the greater part of the $\mathrm{CaP}$ cases. Table 1 show clinicopathological characteristics related to the GG, AG and AA variants. A larger number of patients included in our study were having tumor stage I and II, whereas the patients having tumor stage III and IV were relatively small.

In the cyclin D1 A870G polymorphism, the AA genotype was statistically significantly associated with the dwelling, PSA levels, tumor stage, and histopathological grade (Table 1). The genotype was not statistically significantly associated with the mean age at the time of diagnosis.

\begin{tabular}{|c|c|c|c|c|c|}
\hline \multirow{3}{*}{ Variables } & \multicolumn{5}{|c|}{ Cases $(n=129)$} \\
\hline & Total & GG & A/G & AA & \multirow{2}{*}{$\begin{array}{l}\mathbf{P} \\
\text { Value } \\
; \mathrm{X}^{2}\end{array}$} \\
\hline & $\begin{array}{l}N=129 \\
(\%)\end{array}$ & $\begin{array}{l}29 \\
(22.4 \%)\end{array}$ & $\begin{array}{l}36 \\
(27.9 \%)\end{array}$ & $\begin{array}{l}64 \\
(49.61 \%)\end{array}$ & \\
\hline \multicolumn{6}{|l|}{ Age } \\
\hline$>50$ & $\begin{array}{l}13 \\
(10.0 \%)\end{array}$ & $\begin{array}{l}03 \\
(23.07 \%)\end{array}$ & $\begin{array}{l}04 \\
(30.7 \%)\end{array}$ & $\begin{array}{l}06 \\
(46.15 \%)\end{array}$ & $\begin{array}{l}0.56 \\
1.12\end{array}$ \\
\hline$\leq 65$ & $\begin{array}{l}116 \\
(90.0 \%)\end{array}$ & $\begin{array}{l}25 \\
(21.55 \%)\end{array}$ & $\begin{array}{l}32 \\
(27.5 \%)\end{array}$ & $\begin{array}{l}59 \\
\% 5)\end{array}$ & \\
\hline \multicolumn{6}{|l|}{ Dwelling } \\
\hline Rural: & $\begin{array}{l}45 \\
(34.6 \%)\end{array}$ & $\begin{array}{l}08 \\
(17.77 \%)\end{array}$ & $\begin{array}{l}12 \\
(26.66 \%)\end{array}$ & $\begin{array}{l}25 \\
(55.55 \%)\end{array}$ & $\begin{array}{l}0.52 \\
1.21\end{array}$ \\
\hline Urban: & $\begin{array}{l}84 \\
(65.4 \%)\end{array}$ & $\begin{array}{l}23 \\
(27.38 \%)\end{array}$ & $\begin{array}{l}28 \\
(33.33 \%)\end{array}$ & $\begin{array}{l}33 \\
(39.28 \%)\end{array}$ & \\
\hline \multicolumn{6}{|c|}{ Pesticide Exposure } \\
\hline Low & $\begin{array}{l}44 \\
(34.6 \%)\end{array}$ & $\begin{array}{l}05 \\
(11.3 \%)\end{array}$ & $\begin{array}{l}09 \\
(20.4 \%)\end{array}$ & $30(68.1 \%)$ & $\begin{array}{l}0.06 \\
4.98\end{array}$ \\
\hline High & $\begin{array}{l}85 \\
(65.4 \%)\end{array}$ & $\begin{array}{l}20 \\
(23.5 \%)\end{array}$ & $\begin{array}{l}29 \\
(34.1 \%)\end{array}$ & $36(42.3 \%)$ & \\
\hline \multicolumn{6}{|l|}{ PSA Levels } \\
\hline Low (4-8) & $\begin{array}{l}35 \\
(27.7 \%)\end{array}$ & $\begin{array}{l}05 \\
(14,2 \%)\end{array}$ & $\begin{array}{l}06 \\
(17.1 \%)\end{array}$ & $24(68.5 \%)$ & $\begin{array}{l}0.04 \\
6.02\end{array}$ \\
\hline High (8-13) & $\begin{array}{l}94 \\
(72.3 \%)\end{array}$ & $\begin{array}{l}23 \\
(24.4 \%)\end{array}$ & $\begin{array}{l}32 \\
(34.0 \%)\end{array}$ & $39(41.4 \%)$ & \\
\hline \multicolumn{6}{|l|}{ Tumor Stage } \\
\hline$I+I I(a+b)$ & $\begin{array}{l}72 \\
(55.4 \%)\end{array}$ & $\begin{array}{l}19 \\
(26.3 \%)\end{array}$ & $\begin{array}{l}20 \\
(27.7 \%)\end{array}$ & $33(45.8 \%)$ & $\begin{array}{l}0.05 \\
4.96\end{array}$ \\
\hline III $(a+b)+I V$ & $\begin{array}{l}57 \\
(44.6 \%)\end{array}$ & $\begin{array}{l}09 \\
(16.7 \%)\end{array}$ & $\begin{array}{l}19 \\
(33.3 \%)\end{array}$ & $29(50.8 \%)$ & \\
\hline \multicolumn{6}{|c|}{$\begin{array}{l}\text { Histopathological } \\
\text { Tumor Grade }\end{array}$} \\
\hline \multicolumn{6}{|l|}{ PD } \\
\hline \multirow[t]{2}{*}{$M D+W D$} & $\begin{array}{l}25 \\
(96.0 \%)\end{array}$ & $\begin{array}{l}07 \\
(28.0 \%)\end{array}$ & $\begin{array}{l}10 \\
(40.0 \%)\end{array}$ & $08(32.0 \%)$ & $\begin{array}{l}0.04 \\
5.32\end{array}$ \\
\hline & $\begin{array}{l}57+47 \\
(24.1 \%)\end{array}$ & $\begin{array}{l}21 \\
(20.1 \%)\end{array}$ & $\begin{array}{l}28 \\
(26.9 \%)\end{array}$ & $55(52.8 \%)$ & \\
\hline
\end{tabular}

Table 1: Association between Cyclin D1 A870G and clinico-pathologic characteristics.

In this study, we observed genotype frequencies in cases and controls were in Hardy-Weinberg equilibrium. The genotype frequencies of Cyclin D1 A870G in cases and controls were observed and it was found that AA genotype is significantly associated with the $\mathrm{CaP}$ cases ( $\mathrm{p}$ value $=0.001)$ (Table 2$)$. 


\begin{tabular}{|l|l|l|l|}
\hline $\begin{array}{l}\text { Cyclin D1 A870G } \\
\text { Genotype }\end{array}$ & Cases & Controls & $\begin{array}{l}\text { OR (95\% Cl); } \\
\text { value }\end{array}$ \\
\cline { 2 - 4 } & $(\mathrm{n}=129)$ & $(\mathrm{n}=221)$ & $\begin{array}{l}0.72 ; 0.41-1.26 ; \\
0.31\end{array}$ \\
\hline GG & $29(22.4 \%)$ & $46(20.81 \%)$ & $\begin{array}{l}0.27 ; 0.18-0.42 ; \\
1.31\end{array}$ \\
\hline AG & $36(27.9 \%)$ & $108(48.86 \%)$ & $2.56 ; 1.47-5.49 ;$ \\
\hline AA & $64(49.61 \%)$ & $25(11.31 \%)$ & 0.001 \\
\hline
\end{tabular}

Table 2: Genotype frequencies of cyclin D1 A870G polymorphism in cases \& controls and their associations with the risk of Prostate Cancer.

\section{Discussion}

$\mathrm{CaP}$ has become a very common disease worldwide. $\mathrm{CaP}$ ranges from indolent localized to aggressive metastatic disease [22-24]. The current study found a strong association of the cyclin D1 A870G polymorphism and the susceptibility of development the CaP. Cyclin $D 1$ plays a key role in regulating various important cellular processes including cell proliferation, differentiation and apoptosis [25]. Cyclin $D 1$ has been also known to play an important role in the transition from the G1 to $S$ phase of the cell cycle [16], and its deregulation has been seen involved in the pathogenesis of several types of cancers [26,27]. Although many polymorphisms of cyclin $D 1$ have been seen associated to different to types of cancer, but $G 870 \mathrm{~A}$ polymorphism is most commonly studied. Till date, numerous studies have reported the role of cyclin D1 G870A polymorphism as a risk factor for $\mathrm{CaP}$ $[8,10,28]$.

As the role of cyclin D1 G870A polymorphism has been as risk factor for prostate cancer in various cases [29]. Therefore, we attempted to study the cyclin D1 G870A polymorphism in CaP patients and control subjects of Kashmiri population. It has been already reported that the Cyclin D1 G870A (Present in splice variant of exon 4) polymorphism is associated to the risk of $\mathrm{CaP}$ [30]. Thus, indicating a possible role of cyclin $D 1$ G870A polymorphism in the development of $\mathrm{CaP}$. The present study included a total of $129 \mathrm{CaP}$ patients; $22.4 \%$ (29 of 129 ) of the patients were homozygous for $\mathrm{G} / \mathrm{G}$ variant, $27.9 \%$ ( 36 of 129 ) were heterozygous for $\mathrm{A} / \mathrm{G}$ and $49.61 \%$ (64 of 129) were homozygous for A/A variant. Whereas the pattern of A870G polymorphism in 221 healthy controls is $11.31 \%$ (25 of 221 ) of the patients were homozygous for A/A variant, $48.86 \%$ (108 of 221) were heterozygous for $\mathrm{A} / \mathrm{G}$ and $20.81 \%$ (46 of 221 ) were homozygous for $\mathrm{G} / \mathrm{G}$ variant.

We also found a significant association between AA variant and PSA levels, suggesting that men who underwent a prostate biopsy due to abnormal (increased) serologic PSA, ultra-sonographic, or clinical findings later presented $\mathrm{CaP}$ in subsequent biopsies.

A significant association was found between the AA variant and rural dwelling, which depicts that in our population, patients from rural areas are at more risk than the urban ones. Furthermore, we found a significant association between the AA variant and the pesticide exposure, which might be because of the patient's occupation. Patients like farmers, which have high pesticide exposure, have shown a significant susceptibility of developing $\mathrm{CaP}$.

We also found a significant association between AA variant and tumor grade III \& IV, which might suggest its role in harboring a higher malignant behavior.
A significant correlation was found between the AA variant and poorly differentiated histopathological grade as has been reported by various earlier studies, suggesting that cyclin D1 A870G SNP may be involved in different mechanisms and possibly also various stages of tumor development.

We also found that the genotype frequencies of $A 870 G$ in cases and controls, where AA genotype is significantly associated with the $\mathrm{CaP}$ cases ( $\mathrm{p}$ value $=0.001$ ), suggesting that the $\mathrm{CaP}$ patients carrying a $\mathrm{AA}$ allele are at much higher risk for $\mathrm{CaP}$.

\section{Conclusion}

In conclusion, our results support the idea of cyclin D1 $A 870 G$ genotypic variance do have a strong association with the $\mathrm{CaP}$ development. The AA genotype was associated with increased of $\mathrm{CaP}$ in Kashmiri men as compare to GG genotype.

\section{Conflict of Interest}

The contributing Authors have no financial or any non-financial competing interests.

\section{References}

1. Peters ME, Ostrander EA (2001) CaP: simplicity to complexity. Nat Genet 27: $134-135$

2. Lichtenstein P, Holm NV, Verkasalo PK, Iliadou A, Kaprio J, et al. (2000) Environmental and heritable factors in the causation of cancer-analyses of cohorts of twins from Sweden, Denmark, and Finland. N Engl J Med 343: 78-85.

3. Zhang Q, Zheng M, Qi XL, Liu F, Mao ZJ, et al. (2014) Effect of NQO1 C609T polymorphism on CaP risk: a meta-analysis. Onco Targets Ther 7: 907-914.

4. Kibel AS, Isaacs WB (2000) G (1)/S cell cycle proteins as markers of aggressive prostate carcinoma. Urology 55: 316-322.

5. Tomlins SA, Mehra R, Rhodes DR, Cao X, Wang L, et al. (2007) Integrative molecular concept modeling of $\mathrm{CaP}$ progression. Nat Genet 39: 41-51.

6. Chang BL, Zheng SL, Isaacs SD, Wiley KE, Turner A, et al. (2004) A polymorphism in the CDKN1B gene is associated with increased risk of hereditary CaP. Cancer Res 64: 1997-1999.

7. Henner WD, Evans AJ, Hough KM, Harris EL, Lowe BA, et al. (2001) Association of codon 72 polymorphism of p53 with lower $\mathrm{CaP}$ risk. Prostate 49: 263-266.

8. Kibel AS, Suarez BK, Belani J, Oh J, Webster R, et al. (2003) CDKN1A and CDKN1B polymorphisms and risk of advanced prostate carcinoma. Cancer Res 63: 2033-2036.

9. Suzuki K, Matsui H, Ohtake N, Nakata S, Takei T, et al. (2003) A p53 codon 72 polymorphism associated with $\mathrm{CaP}$ development and progression in Japanese. J Biomed Sci 10: 430-435.

10. Wang L, Habuchi T, Mitsumori K, Li Z, Kamoto T, et al. (2003) Increase risk of $\mathrm{CaP}$ associated with AA genotype of cyclin D1 gene A870G polymorphism. Int J Cancer 103: 116-120.

11. Sherr CJ (1996) Cancer cell cycles. Science 274: 1672-1677.

12. Han EK, Lim JT, Arber N, Rubin MA, Xing WQ, et al. (1998) Cyclin D1 expression in human prostate carcinoma cell lines and primary tumors. Prostate 35: 95-101.

13. Chen Y, Martinez LA, LaCava M, Coghlan L, Conti CJ (1998) Increased cell growth and tumorigenicity in human prostate LNCaP cells by overexpression to cyclin D1. Oncogene 16: 1913-1920.

14. Drobnjak M, Osman I, Scher HI, Fazzari M, Cordon-Cardo C (2000) Overexpression of cyclin D1 is associated with metastatic CaP to bone. Clin Cancer Res 6: 1891-1895. 
Citation: Hussain F, Hamid A, Majumdhar RS (2017) Risk of Prostate Cancer and Cyclin D1 A870G polymorphism; a Study of Correlation. J

15. Agus DB, Cordon-Cardo C, Fox W, Drobnjak M, Koff A, et al. (1999) CaP cell cycle regulators: response to androgen withdrawal and development of androgen independence. J Natl Cancer Inst 91: 1869-1876.

16. Betticher DC, Thatcher N, Altermatt HJ, Hoban P, Ryder WD, et al. (1995) Alternate splicing produces a novel cyclin D1 transcript. Oncogene 11: 1005-1011.

17. Sawa H, Ohshima TA, Ukita H, Murakami H, Chiba Y, et al. (1998) Alternatively spliced forms of cyclin D1 modulate entry into the cell cycle in an inverse manner. Oncogene 16: 1701-1712.

18. Wang L, Habuchi T, Takahashi T, Mitsumori K, Kamoto T, et al. (2002) Cyclin D1 gene polymorphism is associated with an increased risk of urinary bladder cancer. Carcinogenesis 2002 23: 257- 264.

19. Matthias C, Branigan K, Jahnke V, Leder K, Haas J, et al. (1998) Polymorphism within the cyclin D1 gene is associated with prognosis in patients with squamous cell carcinoma of the head and neck. Clin Cancer Res 4: 2411-2418.

20. Kong S, Amos CI, Luthra R, Lynch PM, Levin B, et al. (2000) Effect of cyclin D1 polymorphism on age of onset of hereditary nonpolyposis colorectal cancer. Cancer Res 60: 249 -252.

21. Simpson DJ, Fryer AA, Grossman AB, Wass JA, Pfeifer M, et al. (2001) Cyclin D1 (CCND1) genotype is associated with tumour grade in sporadic pituitary adenomas. Carcinogenesis 22: 1801-1807.

22. Bracarda S, de Cobelli O, Greco C, PrayerGaletti T, Valdagni R, et al. (2005) Cancer of the prostate. Crit Rev Oncol Hematol 56: 379-396.
23. Mahon KL, Henshall SM, Sutherland RL, Horvath LG (2011) Pathways of chemotherapy resistance in castration-resistant CaP. Endocr Relat Cancer 18: R103-123.

24. Zhang L, Jiao M, Li L, Wu D, Wu K, et al. (2012) Tumorspheres derived from $\mathrm{CaP}$ cells possess chemoresistant and cancer stem cell properties. J Cancer Res Clin Oncol 138: 675-686.

25. Evan GI, Vousden KH (2001) Proliferation, cell cycle and apoptosis in cancer. Nature 411: 342-348.

26. Knudsen KE, Diehl JA, Haiman CA, Knudsen ES (2006) Cyclin D1: polymorphism, aberrant splicing and cancer risk. Oncogene 25: 16201628.

27. Musgrove EA, Caldon CE, Barraclough J, Stone A, Sutherland RL (2011) Cyclin D a therapeutic target in cancer. Nat Rev Cancer 11: 558-572.

28. Mandal RK, Mittal RD (2012) Are cell cycle and apoptosis genes associated with $\mathrm{CaP}$ risk in North Indian population? Urol Oncol 30: 555-561.

29. Zheng, Wan, He, Qi, Liu, et al. (2015) World. J Surg Oncol 13: 55.

30. Wang, Habuchi, Kenji (2003) Increased risk of CaP associated with aa genotype of cyclin d1 gene a870g polymorphism. Int J Cancer 103: 116120. 